\title{
DIVERSITY OF PLASTIC DEGRADING MICROORGANISMS AND THEIR APPRAISAL ON BIODEGRADABLE PLASTIC
}

\author{
POONAM, K. ${ }^{1}$ - RAJABABU, V. ${ }^{1}-$ YOGEShWARI, J. ${ }^{1}$ - PATEL, H. ${ }^{1}{ }^{*}$ \\ ${ }^{1}$ Department of Microbiology \& Biofertilizer Project, B. A. College of Agriculture, \\ Anand Agricultural University, Anand, Gujarat-388110, India \\ (phone: +912692 260211; fax: +912692 260211) \\ *Corresponding author \\ e-mail: hirenpatel_84@yahoo.co.in
}

(Received $19^{\text {th }}$ March 2013; accepted $28^{\text {th }}$ October 2013)

\begin{abstract}
Efforts on isolation of native plastic adoring beneficial microorganism from landfills of three different geographical niches were carried out following testing of their ability to degrade biodegradable polyethylene in laboratory appraisal of identified native microorganisms; Aspergillus terreus Gr., Aspergillus wentii Gr., Emericella nidulans (Eidam), Pseudomonas sp. and Streptomyces sp., on different biodegradable polyethylene showed biodegradability in terms of weight loss of plastic in liquid with biofilm formation on plastic strips and it was also noticed that bacteria remained more active compared to fungi in biodegradation process. Amylase production by proven microorganisms showed that A.terreus produced maximum amylase followed by E.nidulans, A.wentii, Pseudomonas sp. and Streptomyces sp. Bio-efficacy of microorganisms against different BD PE in pots indicated that colonization of plastic was not found up to 3 month interval by all of them but E.nidulans found to colonizing IPCL plastic and A.wentii colonizing Israel plastic at 6 month interval.
\end{abstract}

Keywords: isolation, biofilm, percent weight loss, enzyme activity

\section{Introduction}

Plastics are one of the most resource efficient and versatile materials currently available. Total plastics consumption and, consequently, the amount of generated plastic waste have increased continuously during the past few years (Aguado et al., 2006). Million tones of synthetic polymers (plastics) are produced worldwide every year, out of which the most commonly used plastics are Polyethylene (PE), Polypropylene (PP) and Polycarbonate (PC) belonging to thermoplastic group (Zheng et al., 2005). Plastics are resistant against microbial attack, since during their short time of presence in nature evolution could not design new enzyme structures capable of degrading synthetic polymers. Nowadays, a wide variety of petroleum based synthetic polymers are produced worldwide to the extent of approximately 140 million tons per year and remarkable amounts of these polymers are introduced in the ecosystem as industrial waste products. The plastic waste is disposed off through land filling, incineration and recycling. Because of their persistence in our environment, several communities are now more sensitive to the impact of discarded plastic on the environment, including deleterious effects on wildlife and on the aesthetic qualities of cities and forests. Improperly disposed plastic materials are a significant source of environmental pollution, potentially harming life (Shah et al., 2008). Hence a number of countries have banned the use of plastics in last decade for the safe of the environment. Use of plastic in agriculture has tremendously increased in different practices like mulching, soil solarization, tarping, drip irrigation, shading, lining, grafting, wind-breaker, packaging material for seeds, fertilizers and pesticides; for providing protection to plants and post 
harvests, agri-nets etc over last six decades. Modern age concepts of green house and poly house cultivation in floriculture, agriculture, forestry and horticulture are totally plastic dependent. An average of 140 million tons of plastics is used for different purposes worldwide with 57 million tons plastic waste generation annually (Bollag et al., 2000). The world consumption of plastic materials in agriculture amounts yearly to 6.5 million tons, more than $10 \%$ of the total consumption refers to plastic films for soil mulching (Liu et al., 2010).

Biodegradable plastics has gained importance, which gets degraded in litter in few months (6-8 months) to years (2-5 years) depending on type, thickness and gauze (Allen et al., 1999). Only microorganisms have capacity to utilize Polyurethane (PU) as a sole source of carbon and nitrogen and degrading it by polyurthenase and other enzymes (Howard, 2003). Number of researchers' world over has reported a group of polymer degrading enzymes (depolymerases) responsible for biodegradation of plastic. Microbial enzymes commonly involved in degradation of biodegradable plastics are extra or intracellular depolymerases e.g. amylases, magnase peroxidase, polyurethanase, cutinase etc (Premraj and Mukesh, 2004). In view of the serious environmental pollution and health hazards by plastic waste accumulation In the present investigation isolation of plastic adoring native microorganisms from the different environmental niches at Anand and surrounding landfills was attempted, followed with their impact in decomposition of currently marketed biodegradable plastics during 2008 through 2010 in the laboratory with estimation of amylase production by isolates.

\section{Material and methods}

\section{Isolation of Plastic adoring microorganisms}

Different locations soil samples (total of 10 samples) with waste material were collected from 3 different environmental niches to carry out isolation of plastic adoring native microorganisms. Soil samples were collected from landfills of AAU farms, Anand municipal solid waste deposition and Vitthal Udyog Nagar (GIDC) industrial area. Isolation of microorganisms was carried on Minimal Salt (MS) agar (in $\mathrm{gl}^{-1}$ : $\mathrm{NaNO}_{3} 2.0, \mathrm{~K}_{2} \mathrm{HPO}_{4} 0.3, \mathrm{KH}_{2} \mathrm{PO}_{4} 0.7, \mathrm{KCl} 0.5, \mathrm{MgSO}_{4} .7 \mathrm{H}_{2} \mathrm{O} 0.5, \mathrm{FeSO}_{4} .7 \mathrm{H}_{2} \mathrm{O} 0.1$, Agar $30.0 \& \mathrm{pH}$ 6.5) supplemented with non degraded LLDPE commonly useful for soil solarization / tarping and milk bag waste (LLDPE + HmHDPE) and their pieces served as the sole source of carbon in the medium. Samples were suspended in sterile distilled water (10 g soil in $90 \mathrm{ml} \mathrm{D} / \mathrm{W}, 1: 10$ dilution) and kept on shaker (100 rpm) at $25^{\circ} \mathrm{C}$ for $30 \mathrm{~min}$ for through mixing. Upon settling down of soil particles, supernatant was collected and further diluted up to $10^{-4} / 10^{-6}$ dilutions. Diluted samples $(0.1 \mathrm{ml})$ were inoculated on the above medium for isolation of bacteria and fungi. Plates were incubated at $28 \pm 1^{\circ} \mathrm{C}$ for 3 months. Preliminary identification was carried out based on morphology and pigmentation of colonizing microorganism on plastic pieces and examination under phase-contrast research microscope (Olympus CKX 41, Japan). Suspected bacteria belonging to genus Pseudomonas, Streptomyces and fungi attacking plastic were pure cultured on King's B medium, Yeast Extract Malt Extract agar medium and PDA with streptomycin, respectively. Further all isolates were characterized in details at Agharkar Research Institute, Pune, India (Data not shown). 


\section{Nomenclature}

PE - Polyethylene

PU - Polyurethane

LLDPE - Linear Low Density Polyethylene

HmHDPE - High Molecular weight High Density Polymer

BD PE - Bio Degradable Polyethylene

MS Agar - Minimal Salt Agar

PDA - Potato Dextrose Agar

CFU - Colony Forming Unit

D/W - Distilled Water

\section{Appraisal of promising native microorganisms on biodegradable PE}

To study the appraisal of native isolates, biodegradable plastic films were individually exposed to five native plastic adoring test microorganisms viz., Aspergillus terreus Gr; Aspergillus wentii Gr.; Emericella nidulans (Eidam) Vuill.; Pseudomonas sp. and Streptomyces sp. in laboratory by liquid flask culture technique. Following three different biodegradable plastics $\left(\mathrm{T}_{1}\right.$ to $\left.\mathrm{T}_{4}\right)$ were used as test material in the study.

- Israel BD plastic; procured from Volcani Research Center, Bet Dagan, Israel.

- UK BD plastic $\left(\mathrm{D}_{2} \mathrm{~W}\right)$; imported and marketed by Priti plastic, Mumbai, India.

- Swiss BD plastic; imported by IPCL, Vadodara, India.

- Control (25 $\mu$ LLDPE, non degradable film).

\section{Liquid flask culture technique}

Biodegradable plastic samples were cut into small pieces $(5.5 \times 5.5 \mathrm{~cm})$ along with LLDPE and surface sterilized with ethanol. Plastic films were suspended into $250 \mathrm{ml}$ flask containing $100 \mathrm{ml}$ MS medium (without carbon source). Fungal spores or cells of respective test microorganism were harvested in sterile $\mathrm{D} / \mathrm{W}$ with $0.1 \%$ Tween 80 from mother stock and inoculated @ $1.5 \times 10^{6} / 100 \mathrm{ml}$ in respective test. All the flasks were incubated at $28 \pm 2^{\circ} \mathrm{C}$ for 3 months with occasional shaking on a rotary shaker at $10 \mathrm{rpm}$ for $30 \mathrm{~min}$. Flaks were checked in schedule viz. 0, 2, 4, 8, 16, 32 days to see spore germination, colonization, biofilm development, re-sporulation and apparent attack of microorganism on plastic films. CFU were taken at three month and spore count was also carried out at monthly interval. After three months all test plastic strips were taken out and visual examination for growth was carried out following estimation of $\%$ weight loss of plastic. The biofilm deposited strips were extracted in sterile D/W under aseptic condition; the samples were diluted thousand times to carry out spore count microscopically and for CFU on respective media.

\section{Amylase activity of native plastic adoring microorganisms}

Majority of biodegradable plastics marketed worldwide are mainly starch linked. Hence, amylase activity of native isolates was carried out through variable time method in laboratory (Jayaraman, 1981). Culture suspension of all test microorganisms grown in respective culture media were filtered through Whatman filter paper and filtrate were used as active enzyme to estimate amylase activity. Suspensions kept for $15 \mathrm{~min}$ at $80^{\circ} \mathrm{C}$ in water bath, which served as inactive enzyme. All the flasks were labeled as 1, 2, and 3 for respective microorganisms and $5 \mathrm{ml}$ of $0.01 \mathrm{M}$ phosphate buffer was added. 
Further two $\mathrm{ml}$ of $0.1 \%$ starch solution was added in flaks labeled $2 \& 3$, while in flaks labeled 1 only two $\mathrm{ml} \mathrm{D} / \mathrm{W}$ was added in place of substrate with by addition of $0.01 \mathrm{~N}$ $\mathrm{HCl}$ in all the flaks. Active enzyme $(1 \mathrm{ml})$ was added in flask labeled 1 and inactive enzyme in flask labeled as $2 \& 3$. After addition of enzyme, $4 \mathrm{ml}$ of $0.01 \mathrm{~N}$ Iodine (I2) solution was added in all the flaks and final volume were adjusted to $100 \mathrm{ml}$. Optical Density (O.D.) was measured at $578 \mathrm{~nm}$ after 9 min of incubation at room temperature. The enzyme activity was calculated following formula as below.

Where:

$$
\text { Enzyme activity }\left(\frac{\text { Unit }}{\text { litre }}\right)=\frac{\mathrm{E} 0 \mathrm{xE} 1}{\mathrm{E} 0} \mathrm{x} \mathrm{A} \times \frac{1}{\mathrm{~T}} \mathrm{x} \frac{1}{\mathrm{~V}} \mathrm{x} 1000
$$

$\mathrm{E} 0=$ Observation Blank;

$\mathrm{E} 1=$ Observation (Sample);

$\mathrm{A}=12.35$ in mole of amylase assay system;

$\mathrm{T}=$ Time of incubation

$\mathrm{V}=$ Volume of starch.

\section{Results and discussion}

\section{Isolation of plastic adoring microorganisms}

Enumeration of total bacteria and fungi from different soil samples showed that maximum counts of total bacteria (CFU/g of soil) were found in range of $2.4 \times 10^{4}$ to $3.2 \times 10^{4}$ in the sample collected from municipality landfills followed by agricultural landfills of farms $\left(1.5 \times 10^{3}\right.$ to $\left.2.6 \times 10^{3}\right)$. Industrial landfill samples have low count ranging from $2.7 \times 10^{2}$ to $4.5 \times 10^{2}$. Similarly the maximum fungal count was from $6.5 \times 10^{1}$ to $7.8 \times 10^{1}$ in agricultural farm soil followed by industrial landfill soil $\left(2.4 \times 10^{1}\right.$ to $\left.7.4 \times 10^{1}\right)$ and Anand municipality landfill soil sample $\left(4.5 \times 10^{1}\right.$ to $\left.7.3 \times 10^{1}\right)$. The results showed no significant differences found within different environmental niches soil samples in respect to total fungal counts but the total bacterial counts were found to be significantly better for Anand municipality landfills. Results of isolation study carried out in minimal salt medium supplemented with non degradable LLDPE and HmHDPE pieces showed that bacterial colonization of plastic pieces was observed within one week, whereas visible fungal colonization was observed at 3 month of incubation following streaking of different soil samples (Table 1). Colonization of LLDPE and LLDPE + HmHDPE was observed to be deep chocolate brown, dark green and light brown colored fungal growth from T7, T5 and T3 samples respectively after 3 months (Fig. 1).

Colonized plastic pieces by bacteria and fungi were examined under microscope to confirm their plastic adoring action following simple staining like crystal violet for bacteria and cotton blue for fungi. Preliminary identification of native bacterial and fungal isolates showed peculiar colony characteristics. The suspected bacterial strains were identified based on the keys detailed by Burgey's manual of Systematic bacteriology (Halt et al., 1994) based on morphological characteristics and growth on selective medium. The fungal strains were preliminarily identified based on staining with cotton blue and found to be near Aspergillus (Raper and Fennell, 1987). Fungal isolates were identified in details as Aspergillus terreus Gr., Aspergillus wentii Gr., 
Emericella nidulans (Eidam) Vuill and bacteria as Pseudomonas sp. and Sterptomyces sp. (Fig. 2) at Agharkar Research Institute, Pune (Data not shown).

Table 1. Isolation of plastic adoring microorganisms in MS medium supplemented with non degradable LLDPE and HmHDPE plastic

\begin{tabular}{|c|c|c|c|c|c|}
\hline \multirow{2}{*}{$\begin{array}{l}\text { Source of soil } \\
\text { sample }\end{array}$} & \multirow{2}{*}{ Treatments } & \multicolumn{4}{|c|}{ Colonization of heat degraded LLDPE and Hm HDPE } \\
\hline & & 1 week & 1 month & 2 month & 3 month \\
\hline $\begin{array}{l}\text { A) Agricultural } \\
\text { landfills farms }\end{array}$ & $\begin{array}{c}\mathrm{T}_{1}: \mathrm{AF} \\
\mathrm{T}_{2}: \mathrm{PBF} \\
\mathrm{T}_{3}: \mathrm{HF} \\
\mathrm{T}_{4}: \mathrm{BTRS}\end{array}$ & $\begin{array}{l}0 \\
0\end{array}$ & $\begin{array}{c}\text { White bacterial } \\
\text { colony on } \\
\text { HmHDPE }(+) \\
0 \\
0\end{array}$ & $(++)$ & $\begin{array}{c}0 \\
\text { Colonization of } \\
\text { LLDPE with dark } \\
\text { brown fungal } \\
\text { growth }(++) \\
0\end{array}$ \\
\hline $\begin{array}{l}\text { B) Industrial } \\
\text { landfills }\end{array}$ & $\begin{array}{l}\mathrm{T}_{6}: \mathrm{KPF} \\
\mathrm{T}_{7}: \mathrm{MPF} \\
\mathrm{T}_{8}: \mathrm{SPF}\end{array}$ & $\begin{array}{l}0 \\
0\end{array}$ & $\begin{array}{l}0 \\
0\end{array}$ & 0 & $\begin{array}{c}\text { Colonization of } \\
\text { LLDPE with light } \\
\text { brown fungal } \\
\text { growth }(++) \\
0 \\
\text { LLDPE }+ \text { Hm } \\
\text { HDPE colonized } \\
\text { with black fungal } \\
\text { growth }(++) \\
0\end{array}$ \\
\hline $\begin{array}{l}\text { C) Municipality } \\
\text { landfills }\end{array}$ & $\mathrm{T}_{10}: \mathrm{LBL}$ & $\begin{array}{c}\text { Small } \\
\text { pigmented } \\
\text { colony on } \\
\text { LLDPE (+) } \\
0\end{array}$ & $(++)$ & $(++)$ & $(++)$ \\
\hline
\end{tabular}

AF: Agronomy farm; VPF: Nr. Vallabh plastic factory; PBF: Plant breeding farm; KPF: Nr. Krishna plastic factory; HF: Horticulture farm; MPF: Nr. Maruti plastic factory; BTRSF: BTRS farm; SPF: Nr. Somnath plastic factory; HMP: Behind H M Patel market; LBL: Nr. Lotia Bbhagol Lake

\section{Appraisal of promising native microorganisms on biodegradable PE}

CFU of all test microorganisms were taken from biofilm developed on different BD plastic strips from flask experiment (Fig. 2) at three months period. The data revealed that among different native microorganism, Pseudomonas sp. was found superior among two bacteria and have maximum CFU $1.9 \times 10^{10}$ /plastic strip on UK BD PE (Table 2). Among fungal isolates; A. wentii shown maximum CFU $1.8 \times 10^{10} /$ plastic strip on Israel BD PE followed by $E$.nidulans and $A$. terreus. Treated check, nondegradable LLDPE gave lower CFU ranged from $4.0 \times 10^{7}$ to $6.0 \times 10^{7}$ spores/plastic strip compared to all the treatments. Overall results of the experiment revealed that among bacteria; Pseudomonas sp. found effective showing more affinity towards the UK BD PE. While in case of fungi; $A$. wentii was found most efficient than others showing more affinity towards the Israel BD PE. Moreover, results also indicated that UK and Israel BD PE might have provided more favorable (utilizable) carbon source for growth of respective microorganism. Initial microbial count was $1.5 \times 10^{6}$ spores or cells $/ \mathrm{ml}$ which increased up to $1.0 \times 10^{9}$ spores or cells $/ \mathrm{ml}$ in 3 different BD PE but, 
there was not significant increase in LLDPE and remained constant throughout incubation period. Kathireson (2003) studied polyethylene and plastic degrading microorganisms and observed that, total CFU of plastic attacking bacteria was $4.1 \times 10^{5}$ after two month and increased up to $6.5 \times 10^{5}$ after six month on PE under liquid flask culture technique. Similarly, total spore count of fungi was also recorded up to $4.5 \times 10^{3}$ and $6.3 \times 10^{3}$ after two months and six months, respectively.
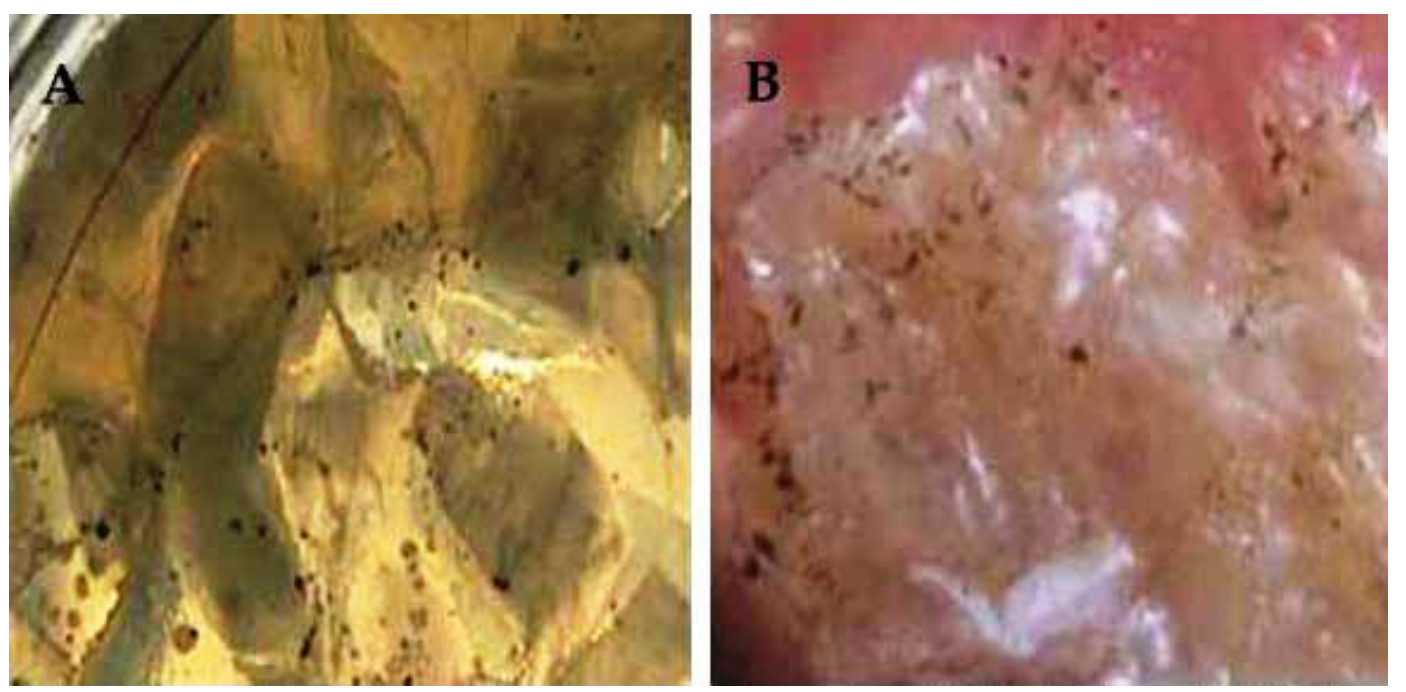

Figure 1. Colonization of fungi on plastic samples. A) Colonization of LLDPE by brown fungus $(10 \mathrm{X})$; B) Colonization of LLDPE by dark brown fungus (10 X)
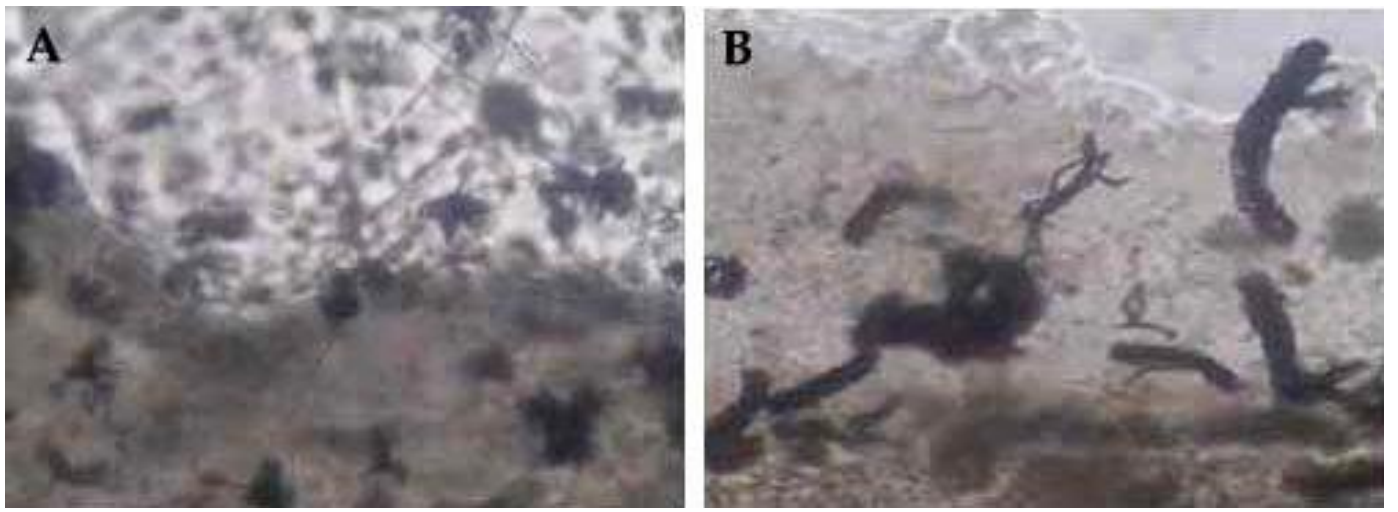

Figure 2. Fungi attacking on plastic film (400 X). A) Aspergillus wentii; B) Emericella nidulans

Results of the weight loss $\%$ showed that among different treatments, $\mathrm{T}_{3}$ was found superior giving maximum weight loss \% up to 16.99 by A. terreus followed by 16.31 , 14.32, 9.84 and 6.98 by A. wentii, E. nidulans, Pseudomonas sp. and Streptomyces sp., respectively after 3 months of incubation. Among fungal isolates; E. nidulans found more effective on biodegradable PE giving weight loss \% of 16.96, 9.62 and 14.32 in $\mathrm{T}_{1}, \mathrm{~T}_{2}$ and $\mathrm{T}_{3}$. Among bacterial isolates; Pseudomonas sp. was found effective showing weight loss $\%$ of $12.25,11.97$ and 9.84 in $\mathrm{T}_{1}, \mathrm{~T}_{2}$ and $\mathrm{T}_{3}$, respectively. Weight loss of non degradable LLDPE was $0.08 \%$ only by different microorganisms. Overall results 
of the weight loss study indicated that, all the native isolates effectively attacked biodegradable PE and fungal isolates were found more aggressive compared to bacterial isolates towards degradation of $\mathrm{BD} \mathrm{PE}$. The reason behind these results may be dominant nature and strong metabolic potential of fungi in compare with bacteria, as well as utilization of complex and almost any organic substance available. Similarly, degradability of degradable PE was tested and \% weight loss of 7.15 was observed after 60 days of incubation with biofilm formation by Penicillium frequentans and Bacillus myscoides (Seneviratne et al., 2006). Weight loss of 0.5 and $0.012 \%$ was increased by individual $P$. frequentans and B. mycoides treatments, respectively (Table 3).

Table 2. CFU of biofilm developed on different BD PE following artificial inoculation in vitro in liquid flask culture technique

\begin{tabular}{c|c|c|c|c|c}
\hline \multirow{2}{*}{ Treatments } & \multicolumn{4}{|c}{ CFU/plastic strip from biofilm developed by native isolates } \\
\cline { 2 - 6 } & M1 & M2 & M3 & M4 & M5 \\
\hline \multirow{2}{*}{$\mathrm{T}_{1}:$ UK BD PE } & $8.94^{*}$ & 10.18 & 8.12 & 10.29 & 7.21 \\
& $\left(8.7 \times 10^{7}\right)^{* *}$ & $\left(1.5 \times 10^{10}\right)$ & $\left(1.3 \times 10^{8}\right)$ & $\left(1.9 \times 10^{10}\right)$ & $\left(1.6 \times 10^{8}\right)$ \\
$\mathrm{T}_{2}$ :IPCL BDPE & 9.84 & 9.43 & 8.22 & 10.10 & 7.4 \\
& $\left(7 \times 10^{9}\right)$ & $\left(2.7 \times 10^{9}\right)$ & $\left(1.6 \times 10^{8}\right)$ & $\left(1.2 \times 10^{10}\right)$ & $\left(2.5 \times 10^{7}\right)$ \\
$\mathrm{T}_{3}:$ Israel BD PE & 10.17 & 10.17 & 10.26 & 9.44 & 7.75 \\
& $\left(1.4 \times 10^{10}\right)$ & $\left(1.4 \times 10^{10}\right)$ & $\left(1.8 \times 10^{10}\right)$ & $\left(2.7 \times 10^{9}\right)$ & $\left(5 \times 10^{7}\right)$ \\
& 7.77 & 7.77 & 7.78 & 7.65 & 7.61 \\
$\mathrm{~S}$. Em & $\left(5.0 \times 10^{7}\right)$ & $\left(5.0 \times 10^{7}\right)$ & $\left(6.0 \times 10^{7}\right)$ & $\left(4.4 \times 10^{7}\right)$ & $\left(4.0 \times 10^{7}\right)$ \\
$\mathrm{CD}(0.05)$ & 0.068 & 0.117 & 0.123 & 0.132 & 0.108 \\
$\mathrm{CV} \%$ & 0.209 & 0.359 & 0.378 & 0.406 & 0.332 \\
& 1.51 & 2.48 & 2.85 & 2.82 & 2.88 \\
\hline
\end{tabular}

* Log transformed values

** Figures in parentheses are retransformed values.

M1 = Aspergillus terreus; M2 = Emericella nidulans; M3 = Aspergillus wentii; M4 = Pseudomonas $\mathrm{sp}$; M5 = Streptomyces sp.

\section{Enzymatic activity of proven native microorganism}

Amylase activity experiment (Table 4) showed that among five different native isolates; A. terreus was found to produce maximum amylase $251.98 \mathrm{U} / \mathrm{L}$ followed by $E$. nidulans (232.01), A. wentii (224.07), Pseudomonas sp. (120.09) and Streptomyces sp. (105.86). Among different treatments, $\mathrm{T}_{3}$ has revealed better amylase activity (U/L) viz., 232.01, 154.80 and 62.08. Treated check $\mathrm{T}_{4}$; non-degradable LLDPE has revealed less amylase activity ranged from 35.64 to $62.08 \mathrm{U} / \mathrm{L}$ by five tested plastic attacking microorganisms. Overall results of amylase activity indicated that all the tested native isolates have significant amylase production when exposed to biodegradable polyethylene compared to non-degradable LLDPE. Which suggests that, the tested BD PE may have starch linked polymers which enhanced or supported biodegradation due to starch hydrolysis by microorganism. Microbial degradation of solid polymer like PE is known to be carried out through enzymatic activity with biofilm formation on plastic. The hydrocarbon chains of polymers have been degraded by enzymes viz., amylase, alkane monoxygenase, polyurethenase and cutinase which are commonly known as 
depolymerases (Seneviratne et al., 2006). Similarly, amylase activity from Streptomyces sp., Aspergillus sp., Mucor racxii and $P$. simplicissimum responsible for plastic degradation up to $6 \%$ on starch linked polymer was reported (Zheng et al., 2005).

Table 3. Weight loss \% of different BD PE increased by native isolates in liquid flask culture technique

\begin{tabular}{c|c|c|c|c|c}
\hline \multirow{2}{*}{ Treatments } & \multicolumn{5}{|c}{ Weight loss \% by native isolates } \\
\cline { 2 - 6 } & M1 & M2 & M3 & M4 & M5 \\
\hline $\mathrm{T}_{1}$ : UK BD PE & 0.05 & 0.04 & 0.05 & 0.04 & 0.05 \\
& $(5.78)^{*}$ & $(16.96)$ & $(4.28)$ & $(12.25)$ & $(2.96)$ \\
$\mathrm{T}_{2}$ : IPCL BD PE & 0.04 & 0.03 & 0.04 & 0.03 & 0.03 \\
& $(7.64)$ & $(9.62)$ & $(7.96)$ & $(11.97)$ & $(9.31)$ \\
$\mathrm{T}_{3}$ : Israel BD PE & 0.03 & 0.04 & 0.04 & 0.04 & 0.04 \\
& $(16.99)$ & $(14.32)$ & $(16.31)$ & $(9.84)$ & $(6.98)$ \\
$\mathrm{T}_{4}$ : Treated check, & 0.05 & 0.05 & 0.05 & 0.05 & 0.05 \\
non-degradable & $(0.08)$ & $(0.08)$ & $(0.08)$ & $(0.08)$ & $(0.08)$ \\
LDPE & 0.0002 & 0.0003 & 0.0002 & 0.0002 & 0.0002 \\
S.Em & 0.0008 & 0.0010 & 0.0008 & 0.0007 & 0.0008 \\
CD $(0.05)$ & 1.204 & 1.49 & 1.14 & 1.02 & 1.15 \\
CV \% & & & & \\
\hline
\end{tabular}

* Figures in parentheses are \% weight loss values.

$\mathrm{M} 1=$ Aspergillus terreus $; \mathrm{M} 2=$ Emericella nidulans; $\mathrm{M} 3=$ Aspergillus wentii $; \mathrm{M} 4=$ Pseudomonas $\mathrm{sp} . ;$ M5 = Streptomyces $\mathrm{sp}$.

Table 4. Amylase activity of native plastic adoring microorganisms

\begin{tabular}{c|c|c|c|c|c}
\hline \multirow{2}{*}{ Treatments } & \multicolumn{4}{|c}{ Amylase activity at 578 nm by native isolates (U/L) } \\
\cline { 2 - 6 } & M1 & M2 & M3 & M4 & M5 \\
\hline $\mathrm{T}_{1}:$ UK BD PE & 105.86 & 232.01 & 90.33 & 120.09 & 76.18 \\
$\mathrm{~T}_{2}$ : IPCL BD PE & 67.36 & 154.80 & 104.30 & 113.03 & 105.86 \\
$\mathrm{~T}_{3}$ : Israel BD PE & 251.98 & 124.30 & 224.07 & 80.05 & 82.33 \\
$\mathrm{~T}_{4}$ : Treated check, & 61.75 & 59.25 & 62.08 & 40.43 & 35.64 \\
non-degradable LLDPE & & & & & \\
\hline
\end{tabular}

M1 = Aspergillus terreus; M2 = Emericella nidulans; M3 = Aspergillus wentii; M4 = Pseudomonas $\mathrm{sp}$; M5 = Streptomyces sp.

\section{Conclusion}

The organisms showed affinity towards the BD plastic indicating them as real plastic loving microorganisms. In order to overcome plastic contamination problem using such beneficial microorganisms having self perpetuating quality in plastic landfills of agricultural or domestic waste depositions will be an obvious choice for green and sustainable environment as well as to protect globe for a long run.

Acknowledgement. We are grateful to Dr. S. K. Singh, Taxonomist \& Scientist, Agharkar Research Institute, Pune, India for identifying and conforming fungus species. 


\section{REFERENCES}

[1] Aguado, J., Serrano, D.P., Vicente, G., Sa'nchez, V. (2006): Effect of Decalin Solvent on the Thermal Degradation of HDPE - Journal of Polymers and the Environment 14: 375384.

[2] Allen, A.B., Hilliard, N.P., Howard, G.T. (1999): Purification and Characterization of a soluble polyurethane degrading enzyme from Comamonas acidovorans - International Biodeterioration Biodegradation 43: 37-41.

[3] Bollag, W.B., Dec, J., Bollage, J.M. (2000): Biodegradation. - In: Elexander, M. (ed.) Encyclopedia of Microbiology, Academic Press, New York: 461-471.

[4] Halt, J.G., Krig, N.R., Sneath, H.A., Staley, J.T., William, S.T. (1994): Burgey's Manual of Systematic Bacteriology. $-9^{\text {th }}$ Edition. Pub. : William and Wilkins, Baltimore.

[5] Howard, G.T. (2003): Biodegradation of polyurethane: a review - International Biodeterioration Biodegradation 40: 245-252.

[6] Jayaraman, J. (1981): Laboratory Manual in Biochemistry. - New age International, New Delhi, India: 77.

[7] Kathiresan, K. (2003): Polyethylene and Plastics-degrading microbes from the mangrove soil - Revista De Biología Tropical 51(3): 629-634.

[8] Liu, M., Huang, Z., Yang, Y.J. (2010): Analysis of biodegradability of three biodegradable mulching films - Journal of Polymers and the Environment 18: 148-154.

[9] Premraj, R., Mukesh, D. (2004): Biodegradation of polymers - Indian Journal of Biotechnology 4: 186-193.

[10] Raper, K.B., Fennell, D.I. (1987): The genus Aspergillus - In: Krieger, R.E. (ed), Huntington, New York: 686.

[11] Seneviratne, G., Tennakoon, N.S., Weerasekara, M.L., Nandaseha, K.A. (2006): Polyethylene biodegradation by a developed Penicillium-Bacillus biofilm - Current Science 90(1): 20-21.

[12] Shah, A.A., Hasan, F., Hameed, A., Ahmed, S. (2008): Biological degradation of plastics: A comprehensive review - Biotechnology Advance 26: 246-265.

[13] Zheng, Y., Yanful, E.K., Bassi, A.S. (2005): A Review of plastic waste Biodegradation Critical Review in Biotechnology 25: 243-250. 